\title{
Pinkus tumor may originate from intraepidermal eccrine ducts and proliferate in the dermis
}

\author{
ICHIRO KUROKAWA ${ }^{1}$, TOMOYA YOKOYAMA ${ }^{1}$, KEISUKE NISHIMURA $^{1}$, ARATA HAKAMADA ${ }^{1}$, \\ KEN-ICHI ISODA ${ }^{1}$, KEI-ICHI YAMANAKA ${ }^{1}$, AIRO TSUBURA ${ }^{2}$ and HITOSHI MIZUTANI ${ }^{1}$ \\ ${ }^{1}$ Department of Dermatology, Mie University Graduate School of Medicine, Mie; \\ ${ }^{2}$ Department of Pathology, Kansai Medical University, Osaka, Japan
}

Received August 17, 2006; Accepted October 3, 2006

\begin{abstract}
To clarify the histopathogenesis of Pinkus tumor (fibroepithelial basal cell carcinoma, FEBCC), we have studied cytokeratin (CK) expression in FEBCC using ten different anti-keratin antibodies against CK 1, 7, 8, 10, 14, $15,16,17,18$ and 19 . Tumor nests consisted of two epithelial components: duct-like structures and basaloid cells of anastomosing strands. In duct-like structure, CK 1, 10, 14, 16, 17 and 19 were detected. CK expression of duct-like structure showed the hyperproliferative state of eccrine intraepidermal ducts. In basaloid cells of anastomosing strands, CK 14 and 17 were detectable. These results suggested that duct-like structure originates from the intraepidermal duct and proliferates to spread in the dermis.
\end{abstract}

\section{Introduction}

Pinkus tumor (fibroepithelial basal cell carcinoma, FEBCC) is an uncommon tumor. It presents as a soft nodular lesion often on the lower part of the back. The histogenesis and origin of FEBCC is unclear (1). The origin of Pinkus tumor might be a consequence of tumor spread along pre-existent dermal eccrine duct (2).

Cytokeratins (CKs), predominant intermediate filaments in keratinocytes, have been catalogued by Moll et al according to their charge and molecular weight (3). CK is a crucial marker to evaluate the origin of epithelial tumors. To our knowledge, no immunohistochemical study of CK in FEBCC has been performed. To elucidate the origin of FEBCC, we have studied $\mathrm{CK}$ expression on FEBCC using ten anti-keratin antibodies.

Correspondence to: Dr Ichiro Kurokawa, Department of Dermatology, Mie University Graduate School of Medicine, 2-174, Edobashi, Tsu, Mie 514-8507, Japan

E-mail: kuroichi@clin.medic.mie-u.ac.jp

Key words: Pinkus tumor, intradermal duct, cytokeratin

\section{Materials and methods}

An 89-year-old man presented with an asymptomatic nodule on the left forearm. The surface of the nodule was erosive with teleangiectasia, and the nodule was elevated and sized $19 \times 12 \mathrm{~mm}$ in diameter with hyperkeratosis in the margin (Fig. 1). No lymph node swelling in the cubital fossa and axilla was observed. The nodular lesion was surgically excised. A specimen was formalin-fixed, paraffin-embedded, stained with haematoxylin and eosin, and PAS stain, and serially-cut sections were used in the immunohistochemical study.

The anti-keratin antibodies used in this study were as follows: 34ßB4 (CK 1) (4), LHP1 (CK 10) (5), LL002 (CK 14) (5), LHK15 (CK 15) (6), LL025 (CK 16) (5), E3 (CK 17) (5), $5 \mathrm{D} 3$ (CK 18) (5) and b170 (CK 19) (7) (all from Novocastra Laboratories Ltd, Newcastle upon Tyne, UK). The immunohistochemical study used the labeled streptoavidin-biotin method (LSAB, Dako, Carpentaria, CA, USA) and was performed as in a previous report (8). Normal skin from the forearm served as controls.

\section{Results}

Hematoxylin and eosin staining. The tumor was composed of two epithelial components: anastomosing strands of basaloid cells and duct-like epithelial cells (Fig. 2). Both epithelium components are partly connected. Between basaloid cells, eosinophilic loose stroma was observed. The tumor nests of basaloid cells revealed hyperchromatinism and atypia, and a reticular pattern, and proliferated downward to the dermis. In addition, duct-like structures within five to ten layers were observed from the epidermis to the upper dermis.

Immunohistochemical findings. CK expression in normal eccrine sweat gland and FEBCC was summarized in Table I as previously reported $(9,10)$. Briefly, CK 1 and 10 were expressed in periluminal and luminal cells in acrosyringium, and in luminal cells in intradermal duct. CK 14 was expressed in basal cells in acrosyringium and intradermal ducts, and myoepithelial cells in secretory portion. CK 7, 8 and 18 were expressed in secretory cells in secretory portion. CK 17 was only expressed in myoepithelial cells in secretory portion. CK 19 was expressed in luminal cells in acrosyringium and 


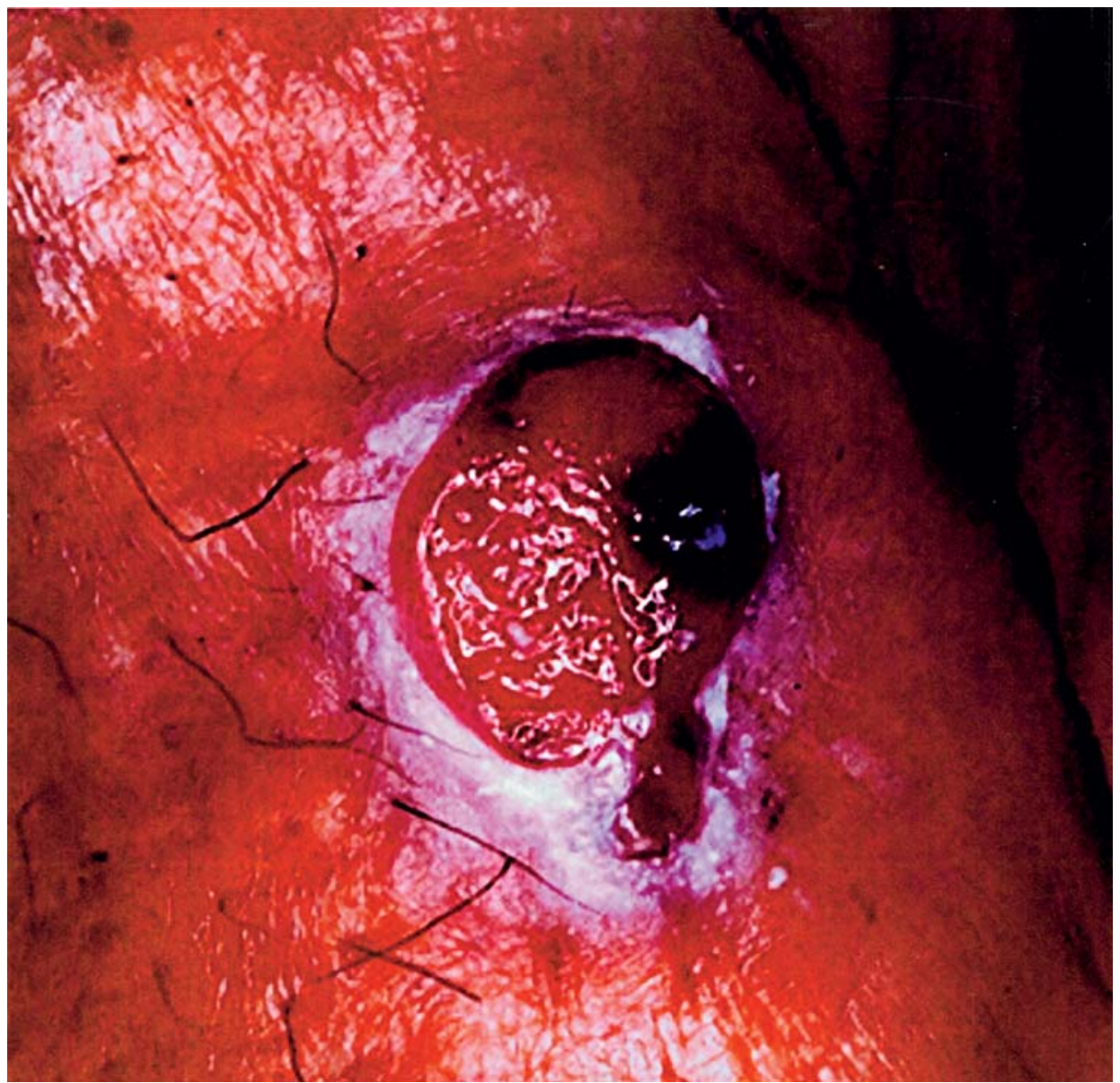

Figure 1. The surface of the nodule was erosive with teleangiectasia. The nodule was elevated and sized 19x12 mm in diameter with hyperkeratosis in the margin.

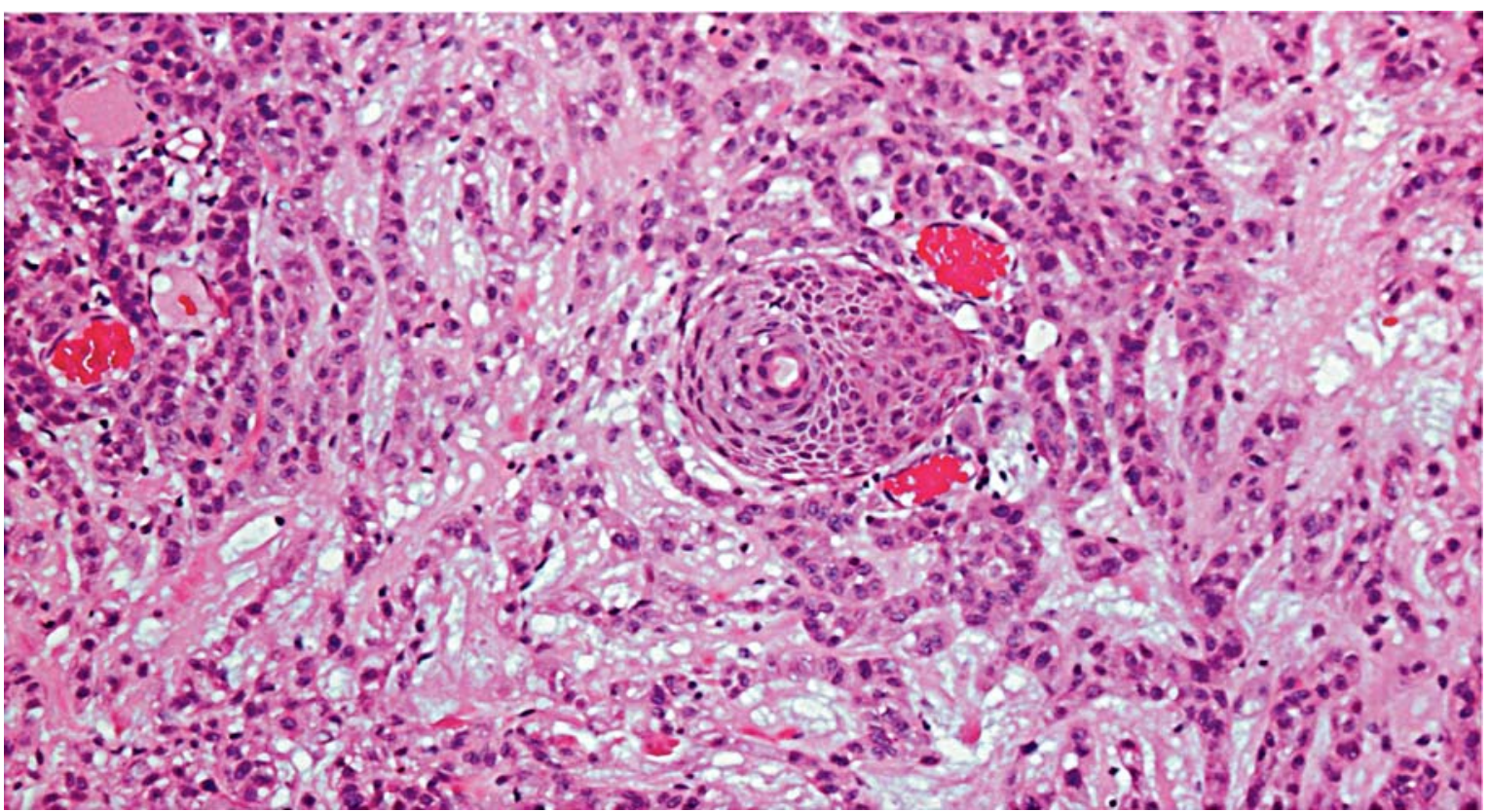

Figure 2. The tumor was composed of two epithelial components: anastomosing strands of basaloid cells and duct-like epithelial cells.

intradermal duct, and secretory cells in secretory portion. CK 15 and 16 were not detected in eccrine sweat gland.
Regarding duct-like structure, CK 1 (Fig. 3) and 10, stratified keratin, were positive for suprabasal layers in duct- 
Table I. CK expression in normal eccrine sweat gland and FEBCC.

\begin{tabular}{|c|c|c|c|c|c|c|c|c|c|}
\hline & \multicolumn{3}{|c|}{ Acrosyringium } & \multicolumn{2}{|c|}{ Intradermal duct } & \multicolumn{2}{|c|}{ Secretory portion } & \multicolumn{2}{|c|}{ FEBCC } \\
\hline & $\begin{array}{l}\text { Luminal } \\
\text { cells }\end{array}$ & $\begin{array}{l}\text { Periluminal } \\
\text { cells }\end{array}$ & $\begin{array}{l}\text { Basal } \\
\text { cells }\end{array}$ & $\begin{array}{l}\text { Luminal } \\
\text { cells }\end{array}$ & $\begin{array}{l}\text { Basal } \\
\text { cells }\end{array}$ & $\begin{array}{l}\text { Secretory } \\
\text { cells }\end{array}$ & $\begin{array}{l}\text { Myoepithelial } \\
\text { cells }\end{array}$ & $\begin{array}{l}\text { Duct-like } \\
\text { structure }\end{array}$ & $\begin{array}{l}\text { Basaloid } \\
\text { cells }\end{array}$ \\
\hline CK 1 & + & + & - & + & - & - & - & + & - \\
\hline CK 7 & - & - & - & - & - & + & - & - & - \\
\hline CK 8 & - & - & - & - & - & + & - & - & - \\
\hline CK 10 & + & + & - & + & - & - & - & + & - \\
\hline CK 14 & - & - & + & - & + & - & + & + & + \\
\hline CK 15 & - & - & - & - & - & - & - & - & - \\
\hline CK 16 & - & - & - & - & - & - & - & + & - \\
\hline CK 17 & - & - & - & - & - & - & + & + & + \\
\hline CK 18 & - & - & - & - & - & + & - & - & - \\
\hline CK 19 & + & - & - & + & - & + & - & $t^{\mathrm{a}}$ & - \\
\hline
\end{tabular}

anly inner cells are positive for CK19.

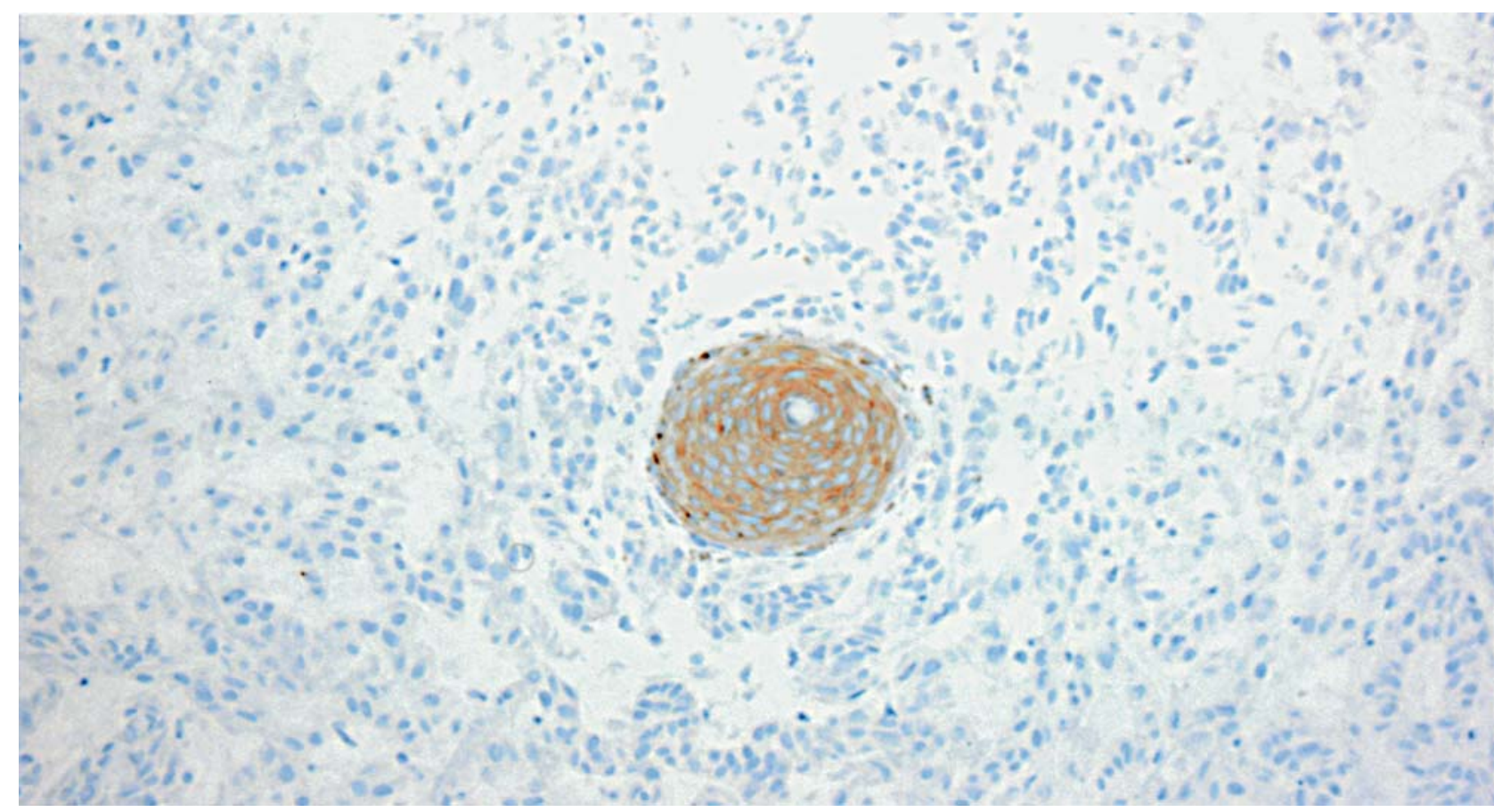

Figure 3. CK 1 was positive for suprabasal layers in duct-like structure.

like structure. CK 14, basal keratin, was also expressed in duct-like structure. CK 16 (Fig. 4) and 17, hyperproliferative keratins, were detectable in the whole layers in the duct-like structure. CK 19 was only expressed in the inner cells (Fig. 5). CK 7, 8 and 18 were not detected.

Concerning basaloid nests, CK 14 and 17 (Fig. 6) were detected in basaloid nests. The other CKs were not expressed.

PAS staining. PAS-positive basement membrane was observed. In duct like structure and basaloid nests, the intensity of PAS was decreased (Fig. 7).

\section{Discussion}

Pinkus tumor (fibroepithelial basal cell carcinoma, FEBCC) was reported as premalignant fibroepithelial tumor of skin (11). Although the histogenesis of FEBCC remains unknown, Stern et al (2) reported that FEBCC spreads along the eccrine ducts histologically. They found focal obliteration of duct and transition to strands of solid BCC, and suggested that eccrine ducts serve as an initial template in FEBCC, resulting in subsequent replacement by solid strands of basal cell carcinoma. 


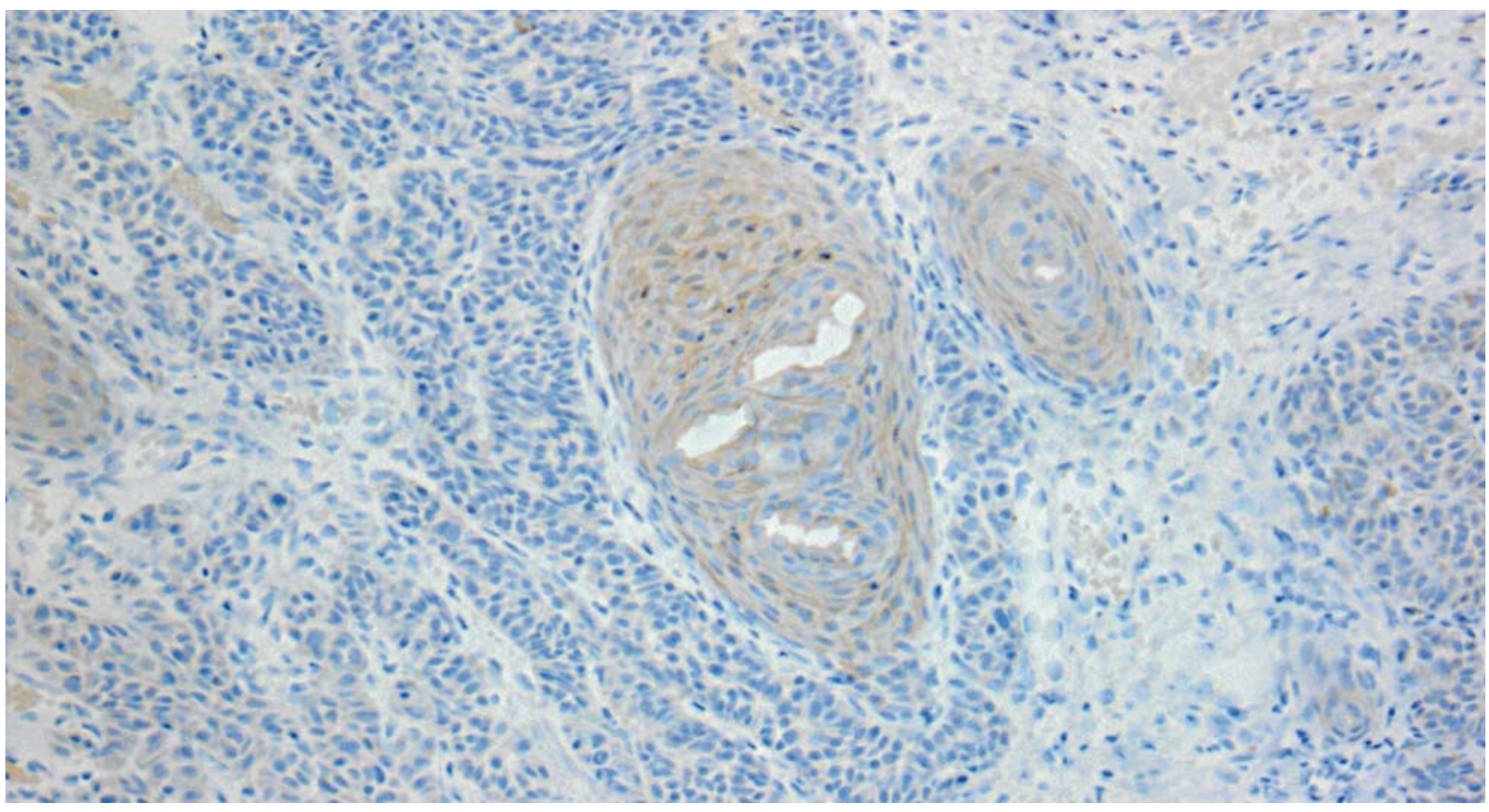

Figure 4. CK 16 was detectable in the whole layers in the duct-like structure. Basaloid nests were negative for CK 16.

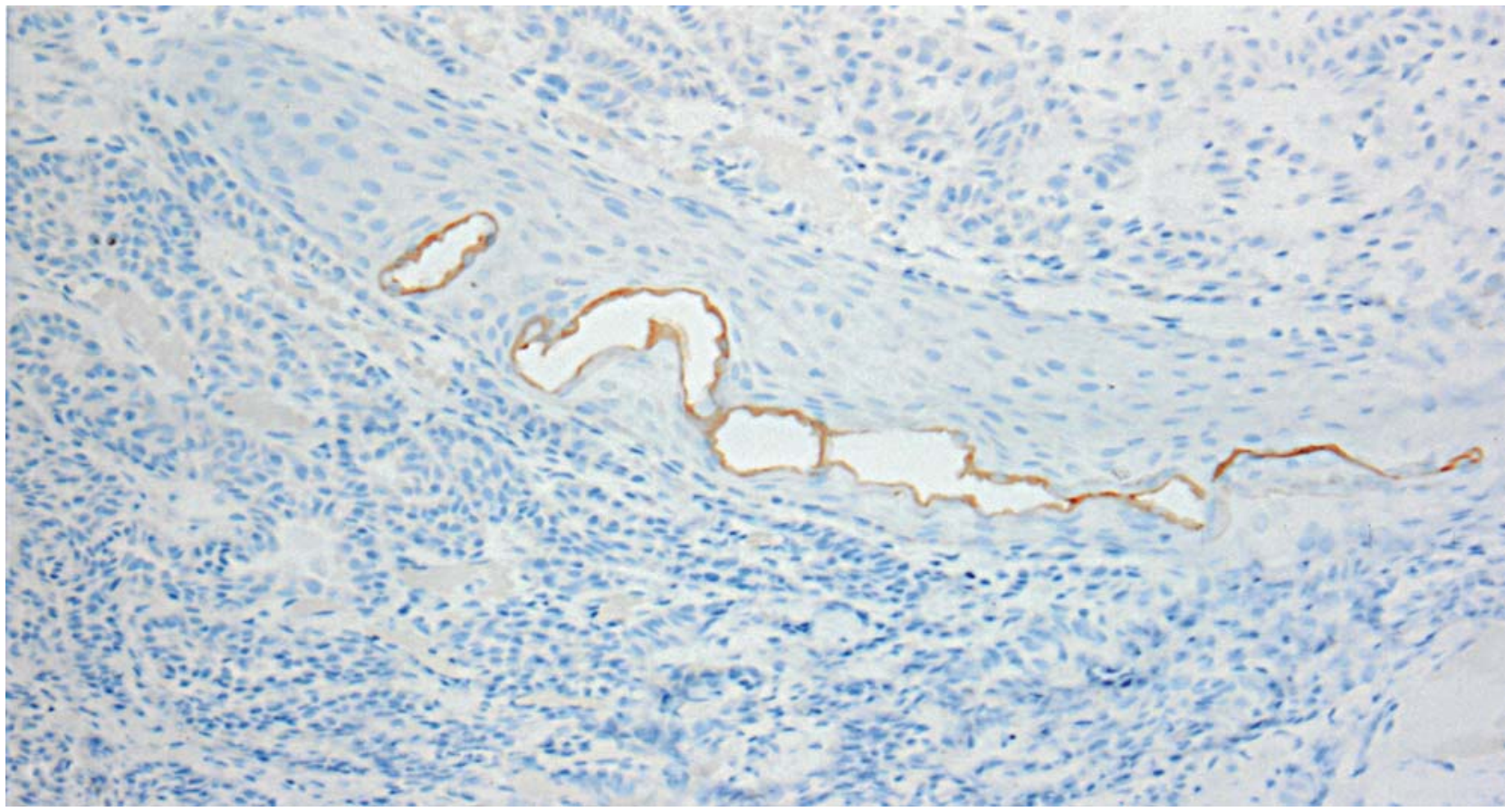

Figure 5. CK 19 was only expressed in the innner cells. Basaloid nests were negative for CK 19.

With regard to duct-like structure, CK 1 and 10, differentiated keratins found in stratified epithelium, were detected in suprabasal layers of ductal-like structure. In normal acrosyringium, CK 1 and 10 are detectable in periluminal and luminal cells (suprabasal cells) in acrosyringium. CK 19, keratin specifically present in luminal cells throughout the eccrine sweat gland, was expressed in inner cells in ductlike structure. These keratins in ductal-like structure were similar to those of normal acrosyringium. CK 14, basal keratin, was expressed in the whole layers of duct-like structure, suggesting that duct-like structure possesses undifferentiated character. To our interest, CK 16 and 17, hyperproliferative keratins which are not detectable in normal acrosyringium and intra-dermal duct, were expressed in ductal structure. These results suggested that duct-like structure originates from intraepidermal duct with CK 1 and 10, and proliferates to 


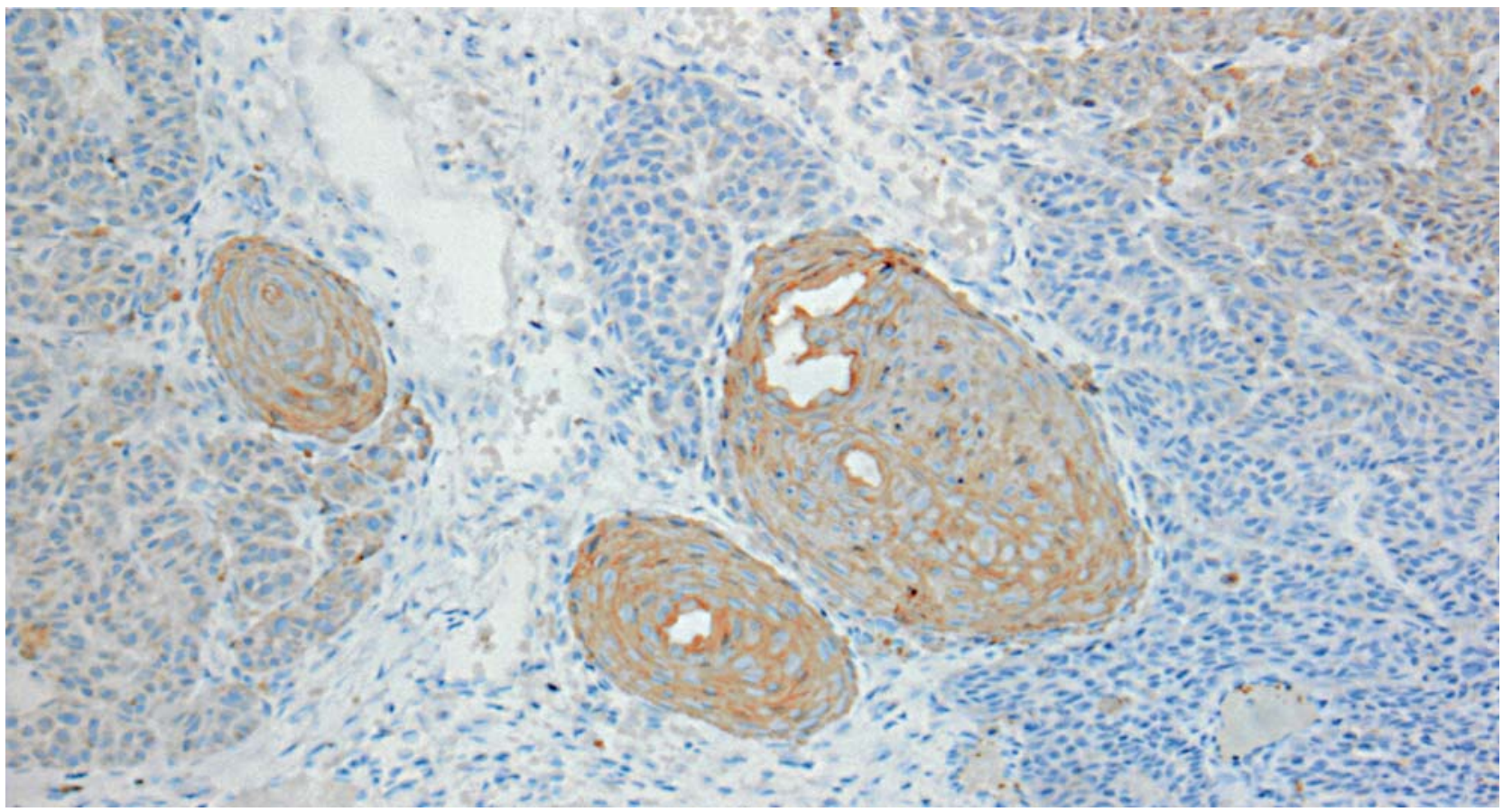

Figure 6. CK 17 were detected in basaloid nests.

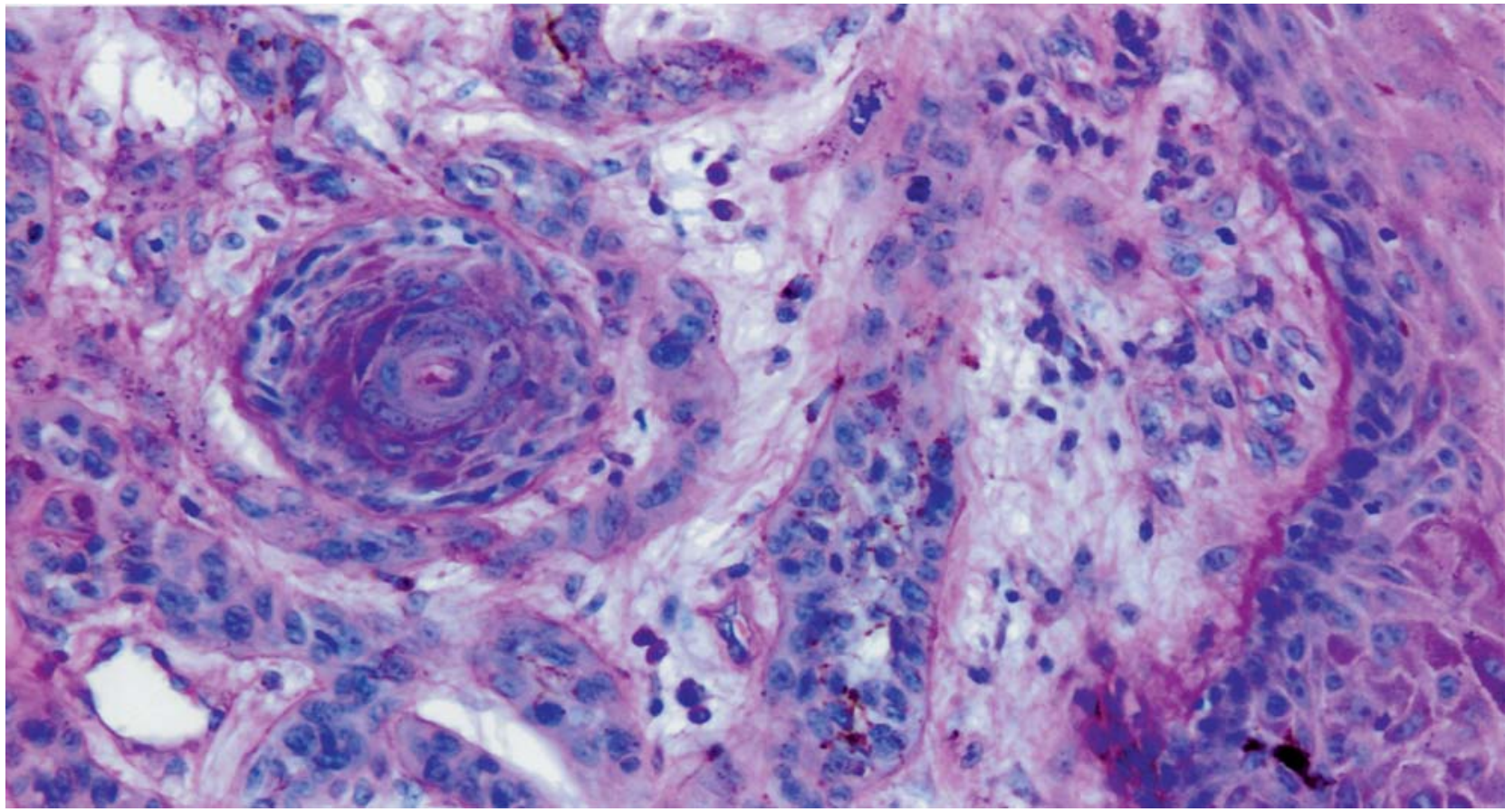

Figure 7. PAS-positive basement membrane was observed. In duct-like structure and basaloid nests, the intensity of PAS was decreased.

spread in the dermis with CK 16 and 17 . We did not find focal obliteration of duct epithelium and lumen as previously reported (2). Roth et al (12) reported that high incidence of FEBCC in BCC of the sole correlates with abundant sweat glands. They also reported CEA immunostaining in the eccrine foci within tumor strands. Our immunohistochemical study supports the previous proposals $(2,12)$ which demonstrate that FEBCC derives from the spread of BCC down eccrine ducts. In addition, we suggest that FEBCC is derived from intraepidermal duct, and proliferates in the dermis with hyperproliferative keratins.

With regard to basaloid nests, CK 14 and 17 were detected in FEBCC. CK expression of FEBCC was similar to that of previous reports $(4,13)$. These reports showed expression of CK 5, 14, and 17 in BCC. CK 1 and 10, stratified keratin, and CK 7 and 18, simple epithelial or embryonic keratin, 
were not detected in BCC $(4,13)$. CK 16 is not found in BCC. CK 19 was found in 4 of 15 cases of BCC (4). Stern et al (2) proposed that eccrine ducts serve as an initial template in FEBCC and subsequently are replaced by BCC.

Further investigations will be needed to clarify the origin of FEBCC.

\section{References}

1. Brenn T and McKee PH: Tumors of the surface epithelium. In: Pathology of the Skin. McKee PH et al (eds). Philadelphia, 3rd edition, pp1186-1187, 2005.

2. Stern JB, Haupt HM and Smith RRL: Fibroepithelioma of Pinkus: Eccrine duct spread of basal cell carcinoma. Am J Dermatopathol 16: 585-587, 1994.

3. Moll R, Franke WW, Schiller D, et al: The catalog of human cytokeratins: patterns of expression in normal epithelia, tumors and cultured cells. Cell 31: 11-24, 1982.

4. Markey AC, Lane EB, McDonald DM and Leigh IM: Keratin expression in basal cell carcinoma. Br J Dermatol 126: 154-161, 1992.

5. Lane EB, Bartek J, Purkis PE and Leigh I: Keratin antigens in differentiating skin. Ann NY Acad Sci 455: 241-258, 1995.
6. Jih DM, Lyle S, Elenitsas R, et al: Cytokeratin 15 expression in trichoepithelioma and a subset of basal cell carcinoma suggests they originate from hair follicle stem cells. J Cutan Pathol 26: 113-118, 1999.

7. Lindberg K and Rheinwald JG: Suprabasal 40kd keratin (K19) expression as an immunohistologic marker of premalignancy in oral epithelium. Am J Pathol 134: 89-98, 1989.

8. Kurokawa I, Nishijima S, Kusumoto K, Senzaki H, Shikata N and Tsubura A: Trichilemmoma: an immunohistochemical study of cytokeratins. Br J Dermatol 149: 99-104, 2003.

9. Kurokawa I, Mayer-da-Silva A and Gollnick H: Presence of cytokeratins in human sweat gland epithelia - an immunohistochemical study of monoclonal antibodies KL1, CK8.60, PKK2, CK8.12, CK8.13, CK4.62, and RPN 1160 using APAAP technique. J Dermatol 15: 308-315, 1988.

10. Langbein L, Rogers MA, Praetzel S, Cribier B, Peltre B and Gassler N: Characterization of novel human type II epithelial keratin K1b specifically expressed in eccrine sweat glands. J Invest Dermatol 125: 428-444, 2005.

11. Pinkus H: Premalignant fibroepithelial tumors of skin. Arch Dermatol 67: 598-615, 1953.

12. Roth MJ, Stern JB, Haupt HM, Smith RRL and Berlin SJ: Basal cell carcinoma of the sole. J Cutan Pathol 22: 349-353, 1995.

13. Asada M, Schaart F-M, de Almeida HL, et al: Solid basal cell epithelioma (BCE) possibly originates from the outer root sheath of the hair follicle. Acta Derm Venereol 73: 286-292, 1993. 